\title{
Restrictive strategy of intraoperative fluid maintenance during optimization of oxygen delivery decreases major complications after high-risk surgery
}

Suzana M Lobo ${ }^{1 *}$, Luis S Ronchi², Neymar E Oliveira', Paulo G Brandão ${ }^{3}$, Adriano Froes ${ }^{3}$, Geni S Cunrath², Kátia G Nishiyama', João G Netinho² and Francisco R Lobo ${ }^{3}$

\begin{abstract}
Introduction: Optimal fluid management is crucial for patients who undergo major and prolonged surgery. Persistent hypovolemia is associated with complications, but fluid overload is also harmful. We evaluated the effects of a restrictive versus conventional strategy of crystalloid administration during goal-directed therapy in high-risk surgical patients.

Methods: We conducted a prospective, randomized, controlled study of high-risk patients undergoing major surgery. For fluid maintenance during surgery, the restrictive group received $4 \mathrm{ml} / \mathrm{kg} / \mathrm{hour}$ and the conventional group received $12 \mathrm{ml} / \mathrm{kg} /$ hour of Ringer's lactate solution. A minimally invasive technique (the LiDCO monitoring system) was used to continuously monitor stroke volume and oxygen delivery index $\left(\mathrm{DO}_{2} \mathrm{l}\right)$ in both groups. Dobutamine was administered as necessary, and fluid challenges were used to test fluid responsiveness to achieve the best possible $\mathrm{DO}_{2}$ I during surgery and for 8 hours postoperatively.

Results: Eighty-eight patients were included. The patients' median age was 69 years. The conventional treatment group received a significantly greater amount of lactated Ringer's solution (mean \pm standard deviation (SD): 4, $335 \pm 1$, $546 \mathrm{ml})$ than the restrictive group (mean \pm SD: $2,301 \pm 1,064 \mathrm{ml})(P<0.001)$. Temporal patterns of $\mathrm{DO}_{2} \mathrm{I}$ were similar between the two groups. The restrictive group had a $52 \%$ lower rate of major postoperative complications than the conventional group ( $20.0 \%$ vs $41.9 \%$, relative risk $=0.48,95 \%$ confidence interval $=0.24$ to $0.94 ; P=0.046$ ).
\end{abstract}

Conclusions: A restrictive strategy of fluid maintenance during optimization of oxygen delivery reduces major complications in older patients with coexistent pathologies who undergo major surgery.

Trial registration: ISRCTN: ISRCTN94984995

\section{Introduction}

Despite unquestionable advances in the field of perioperative care, morbidity and mortality are still high in some groups of patients, particularly in elderly patients with coexisting pathologies or low cardiorespiratory reserve who undergo extensive and traumatic noncardiac surgery $[1,2]$. Multiple organ dysfunction and sepsis are

\footnotetext{
* Correspondence: suzana-lobo@uol.com.br

'Division of Intensive Care, Department of Internal Medicine, Faculdade de Medicina de São José do Rio Preto, Av Faria Lima-5544, São José do Rio Preto, CEP-15090-000, Brazil

Full list of author information is available at the end of the article
}

complications frequently seen after surgery in such patients $[3,4]$.

Global perfusion is usually assessed by calculation of the oxygen delivery index $\left(\mathrm{DO}_{2} \mathrm{I}\right)$. Imbalance between oxygen delivery $\left(\mathrm{DO}_{2}\right)$ and oxygen consumption $\left(\mathrm{VO}_{2}\right)$ can quickly result in irreversible damage to the cells [5]. Perioperative alterations in $\mathrm{DO}_{2}$ are closely correlated to the development of multiple organ failure (MOF) and death [6]. The fundamental principle underpinning goal-directed therapy (GDT), better known in the field of perioperative care as "hemodynamic optimization, "is the optimization of tissue perfusion by manipulating stroke volume (SV), 
hemoglobin and arterial oxygen saturation $\left(\mathrm{SaO}_{2}\right)$ to improve $\mathrm{DO}_{2}$ by using fluids, inotropes and red blood cells.

Several randomized clinical trials and meta-analyses have shown reductions in postoperative complications and mortality rates when preemptive strategies aimed at optimizing tissue perfusion were used in the perioperative period [6-21]. In the past, cardiac output $(\mathrm{CO})$ and $\mathrm{DO}_{2}$ measurements and GDT were performed by means of pulmonary artery catheters [6-10]. Less invasive methods are now available. The esophageal Doppler-derived corrected flow time is the parameter used most frequently [14-18]. Other measurements, such as SV and CO, obtained by pulse contour analysis with a lithium indicator dilution and pulse power analysis conducted using the LiDCO plus system (Cambridge, UK) and a Vigileo monitor (Edwards Lifesciences, Irvine, CA, USA) or continuous hemodynamic monitoring with a PiCCO monitor (Philips Healthcare, Andover, MA, USA) have been incorporated into clinical practice. High-risk surgical patients allocated to postoperative GDT to attain $\mathrm{DO}_{2} \mathrm{I}$ of $600 \mathrm{ml} /$ minute $/ \mathrm{m}^{2}$ measured using the LiDCO system had fewer complications and shorter hospital stays [19].

Perioperative fluid management is a challenge for anesthesiologists and intensivists. The optimal perioperative fluid regimen for major noncardiac surgery is unclear. Some authors have suggested that estimates of ongoing fluid loss that needs to be replaced with crystalloid are certainly excessive [22], and a growing body of evidence demonstrates better outcomes associated with more restrictive fluid replacement strategies [22-29]. These studies were performed using basic monitoring of vital signs, central venous pressure, urine output and body weight. However, high-risk patients who have more traumatic surgery are at a high risk of hypovolemia and cardiac dysfunction, which cannot be detected without more complex monitoring. Moreover, these patients may benefit from GDT. Therefore, in this study of high-risk surgical patients, we evaluated the impact of a restrictive strategy of fluid maintenance compared to a conventional regimen on the incidence of major postoperative complications during GDT aimed at optimizing $\mathrm{DO}_{2} \mathrm{I}$ and reducing serum lactate levels. We also assessed the hemodynamic and perfusion patterns associated with the two regimens.

\section{Materials and methods}

This prospective, randomized, controlled study was approved by the Institutional Review Board at our institution and carried out in the operating room (OR) and 24-bed ICU of a tertiary hospital. This study is registered as ISRCT N94984995. Informed consent was obtained from each patient. Recruitment was interrupted for one year because of lack of funding.
Patients undergoing elective surgery were admitted to the study if their total risk score based a system adapted from the American College of Cardiology/American Heart Association guidelines was $\geq 3$ points [30]. Two points were given for high-risk surgery, one point for intermediate-risk surgery and one point for each clinical predictor (Table 1). Exclusion criteria were refusal of consent, unplanned surgery, unavailability of ICU beds, pregnancy, congestive heart failure (New York Heart Association functional class IV), chronic renal failure (preoperative creatinine $>2.0 \mathrm{mg} / \mathrm{dl}$ or need for dialysis), acute myocardial ischemia prior to enrollment (acute myocardial infarction within six months, evidence of a risk of ischemia based on clinical symptoms or findings of noninvasive tests), lithium therapy, or severe ventricular or supraventricular arrhythmia), life expectancy $<60$ days and palliative treatment. The presence of one of two trained anesthesiologists or intensivists trained in the study procedures was mandatory, and patients were not enrolled if this condition was not met.

\section{Treatment algorithm}

After admission and in the OR, an oxygen catheter (2 L/ minute), a central venous catheter and an arterial catheter for measurement of mean arterial pressure (MAP) were immediately placed, and samples were taken for baseline blood tests. Measurements of hematocrit, sodium, arterial and venous blood gases, and serum lactate were obtained hourly during surgery, every 2 hours for 8 hours in the ICU and 24 hours after ICU admission. Serum C-reactive protein (CRP) and creatinine were measured after admission to the ICU and 24 hours afterward. Electrocardiogram (EKG), pulse oximeter and MAP readings were monitored continuously during the study period. Acidbase and hydroelectrolytic disturbances were corrected according to routine procedures.

A minimally invasive technique utilizing the $\mathrm{LiDCO}^{\mathrm{TM}}$ plus Hemodynamic Monitor system with lithium dilution was applied to continuously monitor $\mathrm{SV}, \mathrm{CO}, \mathrm{DO}_{2} \mathrm{I}$ and systemic vascular resistance index. $\mathrm{DO}_{2} \mathrm{I}$ values, $\mathrm{SV}$, serum lactate and central venous oxygen saturation $\left(\mathrm{S}_{\mathrm{CV}} \mathrm{O}_{2}\right)$ were recorded hourly. A bolus of $10 \mathrm{ml} / \mathrm{kg}$ of $0.9 \%$ saline was administered before the induction of anesthesia in patients in the two groups. The patients were then randomized, using sealed envelopes (in blocks of 10), to one of the two groups: restrictive or conventional fluid maintenance. The surgeons were blinded to the treatment assignments. The conventional group received $12 \mathrm{ml} / \mathrm{kg} /$ hour of lactated Ringer's solution as maintenance fluid during surgery, and the restrictive group received $4 \mathrm{ml} / \mathrm{kg} /$ hour of the same solution.

An epidural catheter was inserted before surgery, and $10 \mathrm{ml}$ of ropivacaine hydrochloride $(0.25 \%)$ was delivered 
Table 1 Risk scoring system (adapted from American College of Cardiology/American Heart Association guidelines)

\begin{tabular}{|c|c|}
\hline Risk category & $\begin{array}{l}\text { Points } \\
\text { assigned }\end{array}$ \\
\hline \multicolumn{2}{|l|}{ High-risk surgery } \\
\hline Gastrectomy & 2 \\
\hline Pancreatectomy & 2 \\
\hline Total colectomy & 2 \\
\hline Total esophagectomy & 2 \\
\hline $\begin{array}{l}\text { Other long surgical procedure associated with } \\
\text { large-volume } \\
\text { fluid shift or blood loss }\end{array}$ & 2 \\
\hline \multicolumn{2}{|l|}{ Intermediate-risk surgery } \\
\hline Endarterectomy & 1 \\
\hline Head and neck & 1 \\
\hline Intraperitonial or intrathoracic & 1 \\
\hline Orthopedic & 1 \\
\hline \multicolumn{2}{|l|}{ Clinical predictor } \\
\hline Age $>60$ years old & 1 \\
\hline $\begin{array}{l}\text { Diabetes (defined as standard taking medication or } \\
\text { not) }\end{array}$ & 1 \\
\hline $\begin{array}{l}\text { Abnormal electrocardiogram (left ventricular } \\
\text { hypertrophy, left bundle branch block, ST-T } \\
\text { abnormalities and atrial fibrillation) }\end{array}$ & 1 \\
\hline $\begin{array}{l}\text { Low functional capacity (inability to climb one } \\
\text { flight of } \\
\text { stairs with a bag of groceries) }\end{array}$ & 1 \\
\hline Arrhythmia (receiving drug therapy) & 1 \\
\hline History of stroke & 1 \\
\hline Arterial hypertension (difficult to control) & 1 \\
\hline $\begin{array}{l}\text { Compensated or previous decompensated } \\
\text { heart failure (defined as standard) }\end{array}$ & 1 \\
\hline $\begin{array}{l}\text { Angina (Canadian Cardiovascular Society } \\
\text { classification system class I or II) or previous infarct } \\
\text { or } \\
\text { Q waves, severe valvopathy (severe valvular } \\
\text { regurgitation } \\
\text { with reduced left ventricular function) }\end{array}$ & 1 \\
\hline Chronic hepatic failure (defined as standard) & 1 \\
\hline $\begin{array}{l}\text { Chronic renal failure (preoperative creatinine }>2.0 \\
\mathrm{mg} / \mathrm{dl} \\
\text { or need for dialysis) }\end{array}$ & 1 \\
\hline $\begin{array}{l}\text { Chronic obstructive pulmonary disease (defined as } \\
\text { standard) } \\
\text { or severe respiratory illness resulting in functional } \\
\text { limitation }\end{array}$ & 1 \\
\hline
\end{tabular}

Patients undergoing elective surgery were admitted to the study if their total score was $\geq 3$ points based on a risk-scoring system adapted from the

American College of Cardiology/American Heart Association guidelines [30].

for postoperative pain relief. To induce anesthesia, the following drugs were used: midazolam 0.05 to $0.10 \mathrm{mg} /$ $\mathrm{kg}$, propofol $2 \mathrm{mg} / \mathrm{kg}$, sufentanil 0.3 to $0.5 \mu \mathrm{g} / \mathrm{kg}$ and atracurium besylate $0.5 \mathrm{mg} / \mathrm{kg}$. Fluid maintenance was achieved by using a balanced technique involving isoflurane, nitrous oxide and oxygen, as well as continuous infusion of sufentanil ( 0.3 to $0.5 \mu \mathrm{g} / \mathrm{kg} / \mathrm{hour}$ ) and atracurium (7 to $10 \mu \mathrm{g} / \mathrm{kg} /$ minute).
The treatment algorithm is shown in Figure 1. The therapeutic goals for both groups were to keep hemoglobin between 8 to $10 \mathrm{mg} / \mathrm{dl}, \mathrm{SaO}_{2}>94 \%$, urine output $>0.5 \mathrm{ml} / \mathrm{kg}$ /hour, core temperature $>36^{\circ} \mathrm{C}$ and $\mathrm{DO}_{2} \mathrm{I}$ as close as possible to or $>600 \mathrm{ml} / \mathrm{minute} / \mathrm{m}^{2}$ by using dobutamine beginning at $2.5 \mu \mathrm{g} / \mathrm{kg} /$ minute and progressively increasing until the goal was reached. Dobutamine administration was interrupted in the presence of predefined adverse events such as persistent tachycardia (an increase by $20 \%$ from baseline), hypotension unresponsive to fluid challenge, angina and/or signs of myocardial ischemia on the EKG.

Fluid responsiveness was tested after the induction of anesthesia and whenever serum lactate increased to $>2.0$ $\mathrm{mEq} / \mathrm{L}$ for two consecutive measurements, diuresis declined to $<0.5 \mathrm{ml} / \mathrm{kg} /$ hour for 2 hours or arterial pulse pressure variation was $\geq 13 \%$. Fluid responsiveness was evaluated by assessing the response of SV to the infusion of $250 \mathrm{ml}$ of gelatin over 20 minutes. If SV increased by > $10 \%$, fluid replacement was maintained to keep the SV at the achieved value for $\geq 10$ minutes.

In the ICU, both groups received $1.5 \mathrm{ml} / \mathrm{kg} /$ hour of lactated Ringer's solution as fluid maintenance. The therapeutic goals in the ICU were the same as in the OR. The same treatment algorithm was used for 8 hours postoperatively. After this period, dobutamine was tapered and then discontinued. In the ICU, the Physiological and Operative Severity Score for the enUmeration of Mortality and morbidity (POSSUM) and respective estimated mortality rates were calculated [31]. The patient was defined as an achiever a $\mathrm{DO}_{2} \mathrm{I}>600 \mathrm{ml} /$ minute $/ \mathrm{m}^{2}$ was attained at at least one time point in the period between the start of surgery and 8 hours after ICU admission.

\section{Outcomes}

Patients were followed until hospital discharge or for 60 days. An investigator who was unaware of patient group allocation evaluated complications retrospectively by analyzing the medical records and all radiological images and laboratory tests. Major complications were defined as any untoward medical event that prolonged hospitalization, was life-threatening or caused death.

Anastomotic leakage and wound dehiscence were considered complications of tissue healing. Cardiac arrhythmias with hemodynamic repercussions, need for antiarrhythmic drugs and arterial hypertension that required sodium nitroprusside for control and/or prolonged ICU stay were considered cardiovascular complications. Severe sepsis and septic shock were defined according to the American College of Chest Physicians/ Society of Critical Care Medicine guidelines [32]. Centers for Disease Control and Prevention definitions were used to diagnose nosocomial infections. Pulmonary emboli were confirmed by spiral computed tomography. Renal 


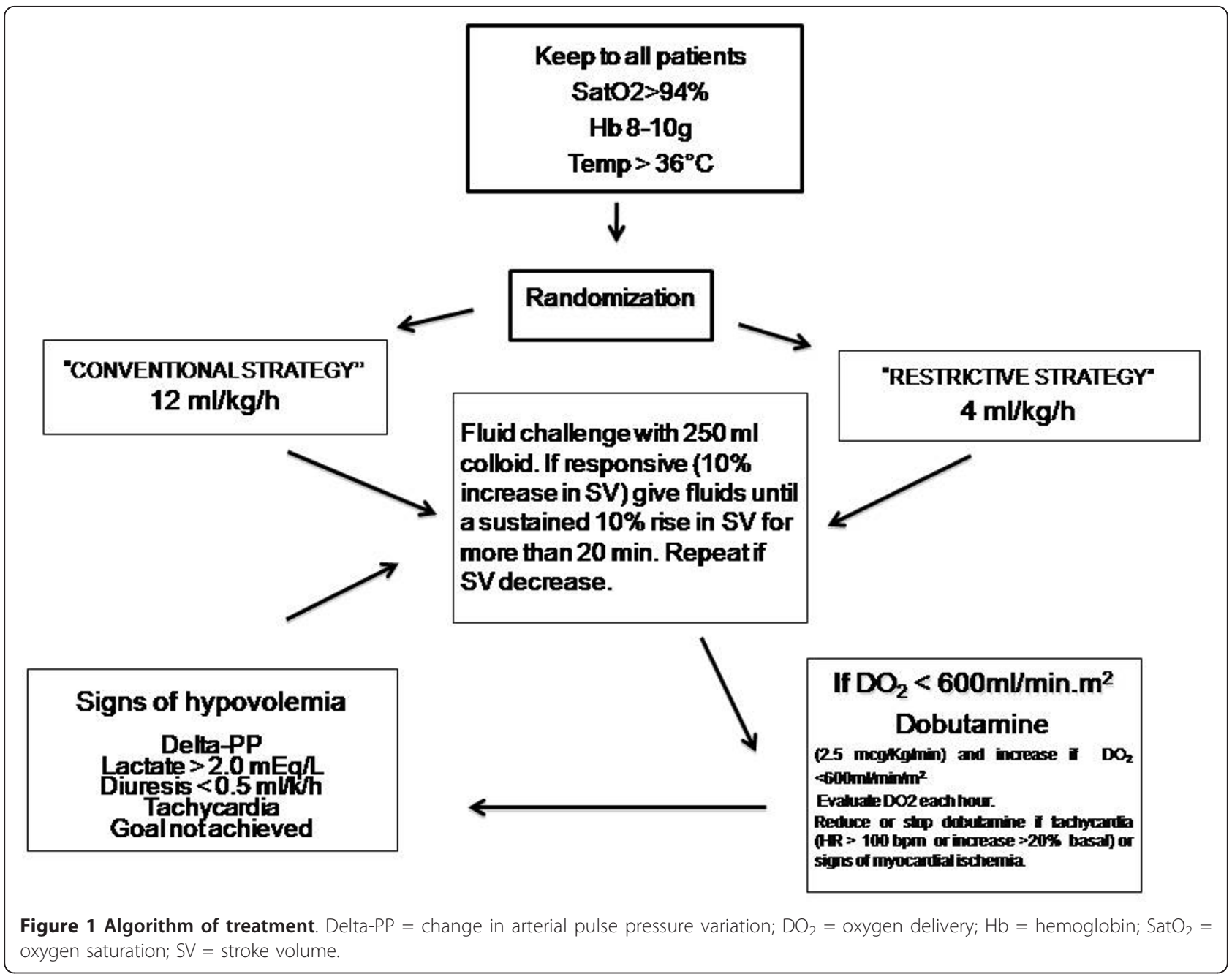

dysfunction was defined as an increase in serum creatinine level by more than twice the baseline level during the postoperative period in patients with previously normal renal function. Gastrointestinal dysfunction was defined as feeding intolerance for more than five days after the operation or the need for parenteral nutrition. Extubation failure was defined as failure to extubate within the first 24 hours after the operation or the need for reintubation within 72 hours after extubation.

\section{Statistical analysis}

The size of the sample was determined based on previous data from our institution showing a morbidity rate of $56 \%$ in patients who received GDT during surgery [33]. To achieve a study power of $80 \%$ and a two-sided test with a significance of $0.05,56$ patients in each group were required in order to decrease the morbidity rate by $46 \%$. The first statistical evaluation, in which we looked for differences in primary outcomes, was scheduled for when $50 \%$ of the planned number of patients were enrolled. At this point, 29 patients were included in the conventional group and 27 were in the restrictive group. At the time of this evaluation, a $50 \%$ decrease in the rate of major complications was noted, and a second interim analysis was planned for when around $80 \%$ of the original planned population was enrolled. At that point, statistically significant differences in major outcomes were identified and the study was terminated.

Continuous variables are presented as means \pm standard deviations or medians with $25 \%$ to $75 \%$ interquartile ranges, and categorical variables are given as numbers and percentages unless otherwise indicated. The KolmogorovSmirnov test was used to verify the normality of distribution of continuous variables. Difference testing between groups was performed using a two-tailed $t$-test and Fisher's exact test as appropriate. Analysis of variance was used for repeated measurements. When there were statistically significant differences, the Bonferroni test was used to detect at which time the differences occurred. The incidence of complications and mortality rates were evaluated 
using relative risk (RR) (95\% confidence interval (CI)). $P<0.05$ was considered statistically significant.

\section{Results}

A total of 116 patients were evaluated for inclusion in the study between February 2006 and July 2010. Eighty-eight patients were randomized, 43 to the conventional group and 45 to the restrictive group. Twenty-eight patients were excluded because of the unavailability of a trained anesthesiologist or intensivist $(n=25)$ or an ICU bed $(n=1)$, acute myocardial infarction within six months of study inclusion $(n=1)$ and arrhythmia $(n=1)$. Because of technical problems, $\mathrm{SV}$ and $\mathrm{DO}_{2}$ data were not available for three patients (all in the restrictive group) in the postoperative period (arrhythmia in one patient and loss of an arterial line in two). Patients were included in the analysis on an intention-to-treat basis.

Demographic and risk-scoring data from both groups are shown in Table 2. No significant differences between groups were found. The median age of the patients was 69 years. Pre-, intra- and postoperative data, therapeutic interventions, and tissue perfusion variables are given in Table 3. The conventional group received a significantly greater amount of lactated Ringer's solution $(4,335 \pm 1$, $546 \mathrm{ml}$ ) during surgery than the restrictive group (2, $301 \pm 1,064 \mathrm{ml})(\mathrm{Mea} \pm \mathrm{SD})(P<0.001)$. However, the restrictive group received a significantly greater amount of colloid $(1,216 \pm 814 \mathrm{ml})$ than the conventional group $(915 \pm 559 \mathrm{ml})(P<0.05)$. The mean doses of dobutamine administered to the conventional and restrictive groups, respectively, were $12.3 \pm 7.3 \mu \mathrm{g} / \mathrm{kg} /$ minute vs $10.9 \pm 5.9 \mu \mathrm{g} / \mathrm{kg} /$ minute intraoperatively $(P=0.32)$ and $9.5 \pm 6.2$ vs $8.0 \pm 4.5 \mu \mathrm{g} / \mathrm{kg} /$ minute postoperatively $(P=0.19)$. There were 26 achievers $(60.4 \%)$ in the conventional group and $18(40 \%)$ in the restrictive group during surgery $(P=0.089)$. After surgery, a larger number of patients in both groups achieved the therapeutic goals (31 $(73.0 \%)$ vs $28(62.2 \%) ; P=0.39)$.

Temporal patterns of $\mathrm{DO}_{2} \mathrm{I}$ were similar between the two groups. After an initial decline following anesthesia induction, $\mathrm{DO}_{2} \mathrm{I}$ recovered similarly in both groups (Figure 2). The $P$ value for the treatment vs time interaction was $<0.0001 . \mathrm{DO}_{2} \mathrm{I}$ levels were maintained at levels higher than baseline most of the time in both groups. Patterns of $\mathrm{DO}_{2} \mathrm{I}$ were also similar in patients with or without complications, regardless of group assignment (data not shown). Serum lactate and $\mathrm{pH}$ did not differ between groups at baseline, ICU admission or 24 hours after surgery (Table 3). $\mathrm{S}_{\mathrm{CV}} \mathrm{O}_{2}$ values were similar at baseline and ICU admission but significantly lower in the restrictive group $(72 \pm 9)$ than in the conventional group $(76 \pm 8)$ after 24 hours $(P<0.05)$.

Table 2 Baseline characteristics of patients in the conventional and restrictive groups

\begin{tabular}{|c|c|c|}
\hline Patient characteristics & Conventional group & Restrictive group \\
\hline Number of patients & 43 & 45 \\
\hline Males (\%) & $24(55.8)$ & $21(47.0)$ \\
\hline Age, years & $68.6 \pm 7.3$ & $69.2 \pm 9.0$ \\
\hline Cancer & $29(67.4)$ & $33(73.3)$ \\
\hline Risk score, points & $4[3$ to 4$]$ & $3[3$ to 4$]$ \\
\hline P-POSSUM physiological score & $24[20$ to 27$]$ & $22[18$ to 27$]$ \\
\hline P-POSSUM operative score & $15[11$ to 17$]$ & $15[14$ to 15$]$ \\
\hline Predicted morbidity rate & $61.5[52.7$ to 82.3$]$ & $61.7[45.7$ to 82.4$]$ \\
\hline Predicted mortality rate & $14.6[11.2$ to 38.2$]$ & $14.5[9.1$ to 28.9$]$ \\
\hline \multicolumn{3}{|l|}{ Clinical predictors } \\
\hline Age $>60$ years & $38(88.3)$ & $40(88.8)$ \\
\hline Arterial hypertension (difficult to control) & $27(62.7)$ & $27(60.0)$ \\
\hline COPD & $4(9.3)$ & $4(8.8)$ \\
\hline Diabetes & $4(9.3)$ & $4(8.8)$ \\
\hline EKG alterations & $4(9.3)$ & $4(8.8)$ \\
\hline Previous AMl & $1(2.3)$ & $3(6.6)$ \\
\hline Previous CVA & $2(4.6)$ & $0(0)$ \\
\hline \multicolumn{3}{|l|}{ Type of surgery } \\
\hline Colorectal & $30(69.7)$ & $38(84.4)$ \\
\hline Vascular & $10(23.2)$ & $4(8.8)$ \\
\hline Orthopedic & $2(4.6)$ & $2(4.4)$ \\
\hline Other & $1(2.3)$ & $1(2.2)$ \\
\hline
\end{tabular}

$\mathrm{AMI}=$ acute myocardial infarction; $\mathrm{COPD}=$ chronic obstructive pulmonary disease; CVA = cardiovascular accident; EKG = electrocardiogram; $\mathrm{P}-\mathrm{POSSUM}=$ Portsmouth predictor equation-modified Physiological and Operative Severity Score for the enUmeration of Mortality and morbidity; SD = standard deviation. Data a presented as $n(\%)$, mean \pm SD or median [ $25 \%$ to $75 \%$ interquartile range]. There were no significant differences between groups. 
Table 3 Therapeutic interventions and changes in perfusion variables in both groups

\begin{tabular}{|c|c|c|}
\hline Variables & Conventional & Restrictive \\
\hline \multicolumn{3}{|l|}{ Therapeutic intervention } \\
\hline \multicolumn{3}{|l|}{ Intraoperative } \\
\hline Operation time, minutes & $228 \pm 53$ & $250 \pm 60$ \\
\hline Crystalloid, ml & $4,335 \pm 1,546$ & $2,301 \pm 1,064^{* *}$ \\
\hline Colloid, ml & $915 \pm 559$ & $1,216 \pm 814^{*}$ \\
\hline Fluid-challenged patients & $42(97.7)$ & $44(97.7)$ \\
\hline Fluid challenges per patient & 2.4 & 3.1 \\
\hline Positive fluid challenges & $61(58.6)$ & $93(65.0)$ \\
\hline Transfused patients (RBCs) & $18(41.8)$ & $19(42.2)$ \\
\hline $\mathrm{RBCs}$, units & $1.8 \pm 0.4$ & $1.9 \pm 0.9$ \\
\hline Dobutamine doses, $\mu \mathrm{g} / \mathrm{kg} /$ minute & $12.3 \pm 7.3$ & $10.9 \pm 5.9$ \\
\hline Achievers & $26(60.4)$ & $18(40.0)$ \\
\hline \multicolumn{3}{|l|}{ Postoperative } \\
\hline Crystalloid, ml & $1,296 \pm 1114$ & $1,145 \pm 680$ \\
\hline Colloid, ml & $1,321 \pm 595$ & $1,210 \pm 700$ \\
\hline RBC transfusions & $10(23.2)$ & $11(24.4)$ \\
\hline RBCs, units & $1.7 \pm 0.7$ & $1.5 \pm 0.5$ \\
\hline Dobutamine dose, $\mu \mathrm{g} / \mathrm{kg} /$ minute & $9.5 \pm 6.2$ & $8.0 \pm 4.5$ \\
\hline \multicolumn{3}{|l|}{ Tissue perfusion } \\
\hline \multicolumn{3}{|l|}{ Preoperative } \\
\hline Serum lactate, mEq/L & $1.3 \pm 0.4$ & $1.3 \pm 0.5$ \\
\hline $\mathrm{S}_{\mathrm{CV}} \mathrm{O}_{2} \%$ & $72 \pm 7$ & $71 \pm 7$ \\
\hline $\mathrm{pH}$ & $7.39 \pm 0.05$ & $7.41 \pm 0.04$ \\
\hline \multicolumn{3}{|l|}{ ICU admission } \\
\hline Serum lactate, mEq/L & $2.51 \pm 1.1$ & $2.6 \pm 1.2$ \\
\hline $\mathrm{S}_{\mathrm{CVO}_{2}} \%$ & $72 \pm 10$ & $74 \pm 10$ \\
\hline $\mathrm{pH}$ & $7.32 \pm 0.06$ & $7.32 \pm 0.07$ \\
\hline \multicolumn{3}{|l|}{24 hours after ICU admission } \\
\hline Serum lactate, mEq/L & $1.9 \pm 0.8$ & $2.0 \pm 0.9$ \\
\hline $\mathrm{S}_{\mathrm{CVO}_{2}} \%$ & $76 \pm 8$ & $72 \pm 9^{*}$ \\
\hline $\mathrm{pH}$ & $7.39 \pm 0.05$ & $7.35 \pm 0.05$ \\
\hline Achievers & $31(73.0)$ & $28(62.2)$ \\
\hline
\end{tabular}

$\mathrm{RBC}=$ red blood cell; $\mathrm{S}_{\mathrm{CVO}_{2}}=$ central venous oxygen saturation; $\mathrm{SD}=$ standard deviation. Data are presented as absolute values, $n$ (\%) or means $\pm \mathrm{SD}$. ${ }^{*}<<0.05$ vs conventional group. ${ }^{* *} P<0.01$ vs conventional group.

All but one patient in each group received at least one fluid challenge. In the conventional group, 104 fluid challenges were performed, of which $58.6 \%$ were positive. In the restrictive group, 143 fluid challenges were performed, of which $65 \%$ were positive (Table 3 ).

There were no differences in pulmonary or renal function between groups at any time (Table 4). Serum levels of CRP for the conventional and restrictive groups were $2.0 \pm 2.5 \mathrm{mg} / \mathrm{dl}$ and $2.1 \pm 2.4 \mathrm{mg} / \mathrm{dl}$ after admission to the ICU, respectively $(P=0.97)$. Twenty-four hours after admission to the ICU CRP levels were $12.0 \pm 5.5 \mathrm{mg} / \mathrm{dl}$ in the conventional group and $11.9 \pm 6.5 \mathrm{mg} / \mathrm{dl}$ in the restrictive group $(P=0.94)$.

In the restrictive group, the rate of major postoperative complications was $52 \%$ less than in the conventional group $(20.0 \%$ vs $41.9 \%, \mathrm{RR}=0.48,95 \% \mathrm{CI}=0.24$ to $0.94 ; P=0.046$ ) (Table 5 ). The 60 -day mortality rates were $6.9 \%$ in the conventional group and $2.2 \%$ in the restrictive group (not significant).

\section{Discussion}

This study is the first in which the effects of two different regimens of fluid maintenance in the setting of GDT and optimization of $\mathrm{DO}_{2}$ have been investigated. The main finding of our study is that there were significantly fewer major complications, particularly with regard to tissue healing and cardiovascular events, in high-risk patients managed with GDT and a more restrictive fluid strategy during major surgery, compared to those managed with a more liberal fluid strategy. Infusion of $4 \mathrm{ml} / \mathrm{kg} /$ hour compared to $12 \mathrm{ml} / \mathrm{kg} /$ hour of lactated Ringer's solution as maintenance fluid during GDT with $\mathrm{DO}_{2}$ - and lactateguided optimization reduced the incidence of major complications by $52 \%$. 


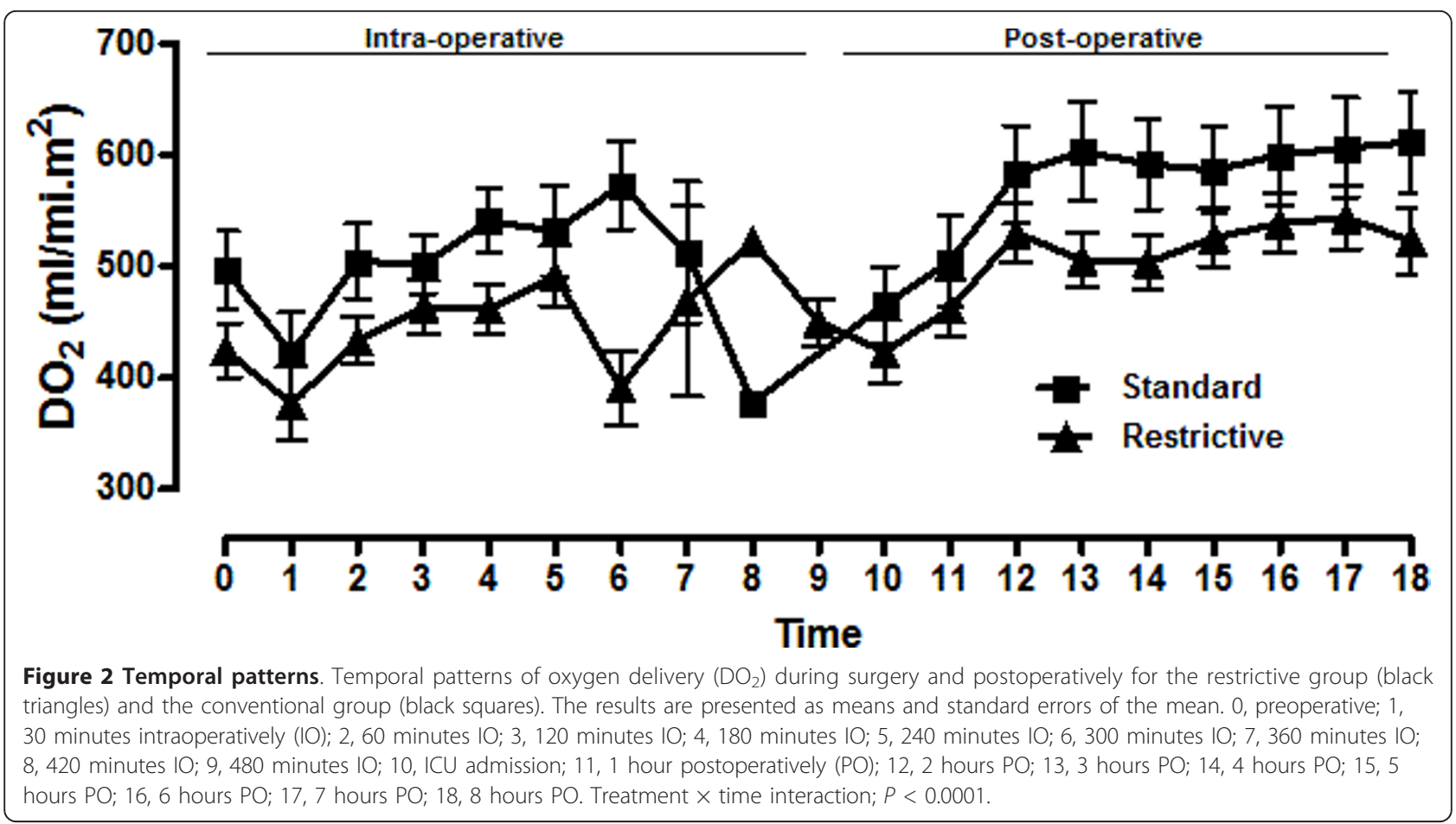

Fluid maintenance during prolonged surgery results in the administration of large amounts of crystalloid, causing weight increases of 3 to $6 \mathrm{~kg}$ [22]. There is a dose-response relationship between complications and increasing body weight on the day of surgery. Positive fluid balance has been associated with more complications and increased mortality in medical and surgical patients admitted to ICUs [34-36].

Interventional studies have compared restrictive regimens of fluid maintenance using more liberal strategies. In a randomized controlled study of 172 patients undergoing colorectal surgery, Brandstrup et al. [22] showed that not replacing fluid loss to the third space and not

Table 4 Renal and pulmonary function in conventional and restrictive groups

\begin{tabular}{|c|c|c|}
\hline Renal and pulmonary function & Conventional & Restrictive \\
\hline \multicolumn{3}{|l|}{ Before surgery } \\
\hline Creatinine, mg/dl & $1.0 \pm 0.4$ & $0.9 \pm 0.3$ \\
\hline $\mathrm{PO}_{2} / \mathrm{FiO}_{2}$ ratio & $438 \pm 220$ & $436 \pm 187$ \\
\hline \multicolumn{3}{|l|}{ ICU admission } \\
\hline Creatinine, mg/dl & $0.9 \pm 0.5$ & $1.1 \pm 1.2$ \\
\hline $\mathrm{PO}_{2} / \mathrm{FiO}_{2}$ ratio & $335 \pm 174^{*}$ & $337 \pm 173^{*}$ \\
\hline \multicolumn{3}{|l|}{24 hours after surgery } \\
\hline Creatinine, mg/dl & $1.2 \pm 0.7$ & $1.0 \pm 0.3$ \\
\hline $\mathrm{PO}_{2} / \mathrm{FiO}_{2}$ ratio & $260 \pm 129^{* *}$ & $248 \pm 109^{* *}$ \\
\hline
\end{tabular}

$\mathrm{PO}_{2} / \mathrm{FiO}_{2}$ ratio = ration of arterial oxygen pressure to fraction of inspired oxygen; $S D=$ standard deviation. All data are means $\pm S D$. ${ }^{*} P<0.05$ vs before surgery; ${ }^{* *} P<0.01$ vs before surgery. giving a volume preload prior to epidural anesthesia was associated with a significant decrease from $56 \%$ to $30 \%$ in postoperative morbidity. In this study, patients in the restrictive group received 3, $200 \mathrm{ml}$ of fluid compared to $6,200 \mathrm{ml}$ in the liberal group [22]. Nisanevich et al. [23] compared $4 \mathrm{ml} / \mathrm{kg} /$ hour with $12 \mathrm{ml} / \mathrm{kg} /$ hour of fluid maintenance during gastrointestinal surgery and reported a similar impact on outcomes. In another study, administration of a median of $3,000 \mathrm{ml}$ compared to $6,300 \mathrm{ml}$ of fluid reduced complications and length of stay in the hospital after colorectal surgery [26]. Restrictive fluid regimens have also been associated with better outcomes in patients undergoing vascular surgery [28,29].

Our study corroborates the findings of these previous publications. It is important to note, however, that, in contrast to our study, these earlier studies were performed in low-risk patients and GDT was not applied simultaneously with surgery. One recent publication compared two strategies of fluid maintenance, $6 \mathrm{ml} / \mathrm{kg} /$ hour of crystalloid in the restrictive group and $12 \mathrm{ml} / \mathrm{kg} /$ hour of crystalloid in the conventional group, integrated with GDT in patients undergoing major surgery [36]. In both groups in that study, a fluid bolus was administered when respiratory variation in peak aortic flow velocity was > 13\%, which was considered indicative of hypovolemia. The incidence of hypovolemia and postoperative complications, especially anastomotic leak and sepsis, was higher in the restrictive group than in the conventional group. Although these 
Table 5 Major complications in conventional and restrictive groups

\begin{tabular}{|c|c|c|}
\hline Complications and outcomes & Conventional $(n=40)$ & Restrictive $(n=41)$ \\
\hline Total complications & 43 & 45 \\
\hline \multicolumn{3}{|l|}{ Cardiovascular complications } \\
\hline Atrial fibrillation & $2(4.6)$ & $1(2.2)$ \\
\hline Hypertensive crisis & $4(9.3)$ & $0(0)$ \\
\hline Pulmonary thromboembolism & $0(0)$ & $1(2.2)$ \\
\hline Total & $6(13.9)$ & $2(4.4)$ \\
\hline \multicolumn{3}{|l|}{ Tissue-healing complications } \\
\hline Evisceration & $2(4.6)$ & $0(0)$ \\
\hline Anastomotic leak & $2(4.6)$ & $1(2.4)$ \\
\hline Total & $4(9.3)$ & $1(2.4)$ \\
\hline \multicolumn{3}{|l|}{ Infectious complications } \\
\hline Nosocomial pneumonia & $4(9.3)$ & $6(13.3)$ \\
\hline Occult septic shock & $1(2.3)$ & $0(0)$ \\
\hline Peritonitis & $2(4.6)$ & $0(0)$ \\
\hline Blood stream infection & $0(0)$ & $1(2.2)$ \\
\hline Wound abscess & $2(4.6)$ & $0(0)$ \\
\hline Total & 9 & 7 \\
\hline \multicolumn{3}{|l|}{ Other complications } \\
\hline Extubation failure & $1(2.3)$ & $0(0)$ \\
\hline Renal dysfunction & $1(2.3)$ & $0(0)$ \\
\hline Gastrointestinal dysfunction & $3(6.9)$ & $1(2.2)$ \\
\hline Total & 5 & 1 \\
\hline Total number of major complications & 24 & 11 \\
\hline Number of patients with complications & $18(41.8)$ & $9(20.0)^{*}$ \\
\hline Number of complications per patient & 0.55 & 0.24 \\
\hline \multicolumn{3}{|l|}{ Outcomes } \\
\hline LOS in the ICU & $2.0[1.0$ to 4.0$]$ & $2.0[2.0$ to 5.0$]$ \\
\hline LOS in the hospital & $6.0[4.0$ to 9.0$]$ & $6.0[4$ to 10$]$ \\
\hline 30-day mortality rate & $2(4.6)$ & $0(0)$ \\
\hline 60-day mortality rate & $3(6.9)$ & $1(2.2)$ \\
\hline
\end{tabular}

LOS $=$ length of stay. Data are presented as absolute values, $n$ (\%) or medians [ $25 \%$ to $75 \%$ interquartile range].

investigators used fluid GDT based on maximization of a flow-related parameter, $\mathrm{DO}_{2}$ was not a target, making direct comparisons with our study difficult.

There are two fundamental aspects of GDT in high-risk surgical patients that must be considered. First, hypovolemia is very common in surgical patients and cannot be detected by routine monitoring of blood pressure, heart rate and central venous pressure. Reduced effective circulating volume may cause various deleterious effects by redirecting flow away from the gut, kidneys and other organs, leading to MOF. At the other extreme, fluid overload in critically ill patients has been associated with various adverse effects, such as prolonged mechanical ventilation, pulmonary edema, abdominal compartment syndrome, infection, longer stay in the ICU and more complications after diverse types of surgery. Therefore, one important component of GDT is to test fluid responsiveness with fluid challenges to minimize the risk of hypo- or hypervolemia. Fluid responders are able to convert fluid loading into a significant increase in $\mathrm{CO}$.

Many studies of GDT have used successive fluid challenges as the main tool of the GDT strategy and have shown improved outcomes mainly as decreased complication rates [12-20]. In older patients, however, fluid challenge unresponsiveness is not infrequently related to myocardial dysfunction or intolerance to fluids. In our study, all but one patient in each group had signs of hypovolemia during surgery as defined by the treatment algorithm. Patients in the restrictive group received more fluid challenges (3.1 per patient) than did patients in the conventional group (2.4 per patient). However, the number of fluid responders was similar between the two groups, demonstrating that although patients in the conventional group received more crystalloid, it did not prevent further signs of hypovolemia, which is likely a reflection of cardiac dysfunction. 
A second important aspect of GDT in high-risk patients is to prevent an imbalance between $\mathrm{DO}_{2}$ and $\mathrm{VO}_{2}$ to avoid multiple organ dysfunction. Many researchers have used dobutamine to achieve higher levels of $\mathrm{DO}_{2} \mathrm{I}$ or cardiac index during prolonged surgery and have reported reduced morbidity and mortality [6-11]. One key difference between our study and the study by Futier et al. [37], apart from the different goal of therapy, is the use of dobutamine. The fact that in our study there were fewer fluid responders suggests that our population had more contractility problems, which is consistent with the older median age of our group. Dobutamine may increase tolerance to fluids and prevent cardiac dysfunction [33]. These data suggest that dobutamine may be important in this group of patients and that $\mathrm{DO}_{2}$ may be a more appropriate goal for hemodynamic optimization therapy in high-risk patients.

Edema of the intestines and other tissues may be responsible for poor tissue healing and other complications. Gut edema may be associated with postoperative gastrointestinal dysfunction, impaired tissue oxygenation and increased intraabdominal pressure. The use of less crystalloid associated with more colloid, by protecting the gut from gastrointestinal dysfunction, may explain the reduced complication rate in the restrictive group. In experimental models, colloid increases microcirculatory blood flow and tissue oxygen tension in the gut mucosa [38]. In a model of gut ischemia in rabbits, crystalloid administration was associated with more gut edema than a combination of colloid with less crystalloid [39]. Patients in the restrictive group received more fluid challenges (3.1 per patient) than did patients in the conventional group (2.4 per patient). As a consequence, they received more colloid. It is possible that the fluid challenges rather than the overall fluid balance benefit patients the most.

It is now recognized that around $15 \%$ of patients undergoing surgery are at high risk of complications and death [40]. Factors associated with increased risk include older age, the presence of comorbid disease and major surgical procedures. In the present study, patients had a median of four comorbidities and a median age of 70 years. Researchers in previous studies have published morbidity rates as high as $70 \%$ in similar groups of patients. A previous study in Brazilian ICUs reported morbidity and mortality rates of $38 \%$ and $20 \%$, respectively, in unselected surgical patients [4]. Major complications occurred in $32 \%$ of patients in an Australian study with a mortality rate of $2 \%$ [41]. The low morbidity and mortality, despite higher rates predicted on the basis of POSSUM scores, suggests that the preemptive use of GDT with fluids and inotropes targeting $\mathrm{DO}_{2}$ improves survival in this group of surgical patients.

Our study has strengths and limitations. First, the volume used as maintenance fluid may be considered too liberal. We deliberately chose a conventional fluid regimen that reflects current clinical practice for fluid administration during major surgical procedures. Textbooks and guidelines indicate a need for 10 to $15 \mathrm{ml} /$ $\mathrm{kg} /$ hour of crystalloids as maintenance fluid in addition to the replacement of blood loss during major and prolonged surgery. The basis for this standard recommendation is an assumed large intravascular volume deficit caused by evaporative loss, fasting and third spacing, all to be replaced by crystalloids. More recent studies have actually shown that extracellular volume expands rather than contracts with fluid balance [42]. Despite earlier studies and several clinical guidelines suggesting benefits associated with a more restrictive or net even approach to fluid therapy, this strategy is still not widely used. Second, this study was performed in only one tertiary center, and its results may not be applicable to other centers. Third, the inability to include consecutive patients because of the limited number of anesthesiologists trained in the procedures used in the study is also a limitation. The main strength of our study is its randomized controlled design and the homogeneous group of high-risk surgical patients.

\section{Conclusions}

Perioperative hemodynamic GDT with a protocol incorporating restrictive fluid maintenance and inotropic therapy to achieve the best possible $\mathrm{DO}_{2}$ in very highrisk surgical patients can be easily performed with the use of minimally invasive hemodynamic monitoring to obtain continuous monitoring of $\mathrm{CO}$ and is related to better patient outcomes. It is possible that with more reliable and easy-to-use hemodynamic monitoring during anesthesia, fluid maintenance volumes might be safely reduced.

\section{Key messages}

- Morbidity and mortality are high in some groups of patients, particularly elderly patients with low cardiorespiratory reserves who undergo extensive noncardiac surgery.

- Perioperative alterations in $\mathrm{DO}_{2}$ are closely correlated to the development of MOF and death.

- Randomized clinical trials have shown reductions in postoperative complications and mortality rates when strategies aimed at optimizing tissue perfusion are used in the perioperative period.

- The optimal perioperative fluid regimen for major noncardiac surgery patients is unclear.

- The preemptive use of GDT with fluids and inotropes targeting $\mathrm{DO}_{2}$ and a more restrictive strategy of fluid maintenance during surgery leads to fewer major complications in high-risk patients undergoing major surgery. 


\section{Acknowledgements}

We thank Bragenix Innovative Technologies for providing the LiDCOTMplus Hemodynamic Monitor used during the study.

\section{Author details}

'Division of Intensive Care, Department of Internal Medicine, Faculdade de Medicina de São José do Rio Preto, Av Faria Lima-5544, São José do Rio Preto, CEP-15090-000, Brazil. ${ }^{2}$ Division of Colorectal Surgery, Department of Surgery, Faculdade de Medicina de São José do Rio Preto, Av Faria Lima5544, São José do Rio Preto, CEP-15090-000, Brazil. ${ }^{3}$ Department of Anesthesiology, Faculdade de Medicina de São José do Rio Preto, Av Faria Lima-5544, São José do Rio Preto, CEP-15090-000, Brazil.

\section{Authors' contributions}

SML contributed to the study design, the statistical analysis, the analysis and interpretation of results, the drafting of the manuscript and critical revisions of the manuscript. LSR contributed to the study design and the acquisition, analysis and interpretation of data. KN was the study coordinator. FRML contributed to the study design, acquisition of data, conduct of the trial, analysis and interpretation of the results and critical revision of the manuscript. NEO and GSC contributed to the study design, acquisition of data and conduct of the trial. PGB contributed to the acquisition of data, the conduct of the trial and the analysis and interpretation of results. AF contributed to the acquisition of data and the conduct of the trial. JGN contributed to the study design and acquisition of data.

\section{Competing interests}

The authors declare that they have no competing interests.

Received: 28 June 2011 Revised: 16 August 2011

Accepted: 23 September 2011 Published: 23 September 2011

\section{References}

1. Cullinane M, Gray AJG, Hargraves CMK, Lansdown M, Martin IC, Schubert M: The 2003 report of the National Confidential Enquiry into Perioperative Deaths.[http://www.ncepod.org.uk/pdf/2003/03full.pdf].

2. Fowkes FG, Lunn JN, Farrow SC, Robertson IB, Samuel P: Epidemiology in anaesthesia. III: Mortality risk in patients with coexisting physical disease. Br J Anaesth 1982, 54:819-825.

3. Shoemaker WC, Appel PL, Kram HB: Role of oxygen debt in the development of organ failure sepsis, and death in high-risk surgical patients. Chest 1992, 102:208-215.

4. Lobo SM, Rezende E, Knibel M, Silva N, Páramo JA, Nácul FE, Mendes $C L$, Assunção M, Costa RC, Grion CC, Pinto SF, Mello PM, Maia MO, Duarte PA, Gutierrez F, Silva JM Jr, Lopes MR, Cordeiro JA, Mellot C: Early determinants of death due to multiple organ failure after noncardiac surgery in high-risk patients. Anesth Analg 2011, 112:877-883.

5. Barbee RW, Reynolds PS, Ward KR: Assessing shock resuscitation strategies by oxygen debt repayment. Shock 2010, 33:113-122.

6. Shoemaker WC, Appel PL, Kram HB, Waxman K, Lee T: Prospective trial of supranormal values of survivors as therapeutic goals in high risk surgical patients. Chest 1988, 94:1176-1185.

7. Boyd O, Grounds RM, Benett ED: A randomized clinical trial of the effect of deliberate perioperative increase of oxygen delivery on mortality in high-risk surgical patients. JAMA 1993, 270:2699-2707.

8. Wilson J, Woods I, Fawcett J, Whall R, Dibb W, Morris C, McManus E: Reducing the risk of major surgery: randomised controlled trial of preoperative optimisation of oxygen delivery. BMJ 1999, 318:1099-1103.

9. Lobo SM, Salgado PF, Castillo VG, Borim AA, Polachini CA, Palchetti JC, Brienzi SL, de Oliveira GG: Effects of maximizing oxygen delivery on morbidity and mortality in high-risk surgical patients. Crit Care Med 2000, 28:3396-3404.

10. Berlauk JF, Abrams JH, Gilmour IJ, O'Connor SR, Knighton DR, Cerra FB: Preoperative optimization of cardiovascular hemodynamics improves outcome in peripheral vascular surgery. Ann Surg 1991, 214:289-297.

11. Donati A, Loggi S, Preiser JC, Orsetti G, Münch C, Gabbanelli V, Pelaia P, Pietropaoli P: Goal-directed intraoperative therapy reduces morbidity and length of hospital stay in high-risk surgical patients. Chest 2007, 132:1817-1824.

12. Pölönen $\mathrm{P}$, Ruokonen $\mathrm{E}$, Hippeläinen $\mathrm{M}$, Pöyhönem M, Takala J: A prospective, randomized study of goal-oriented hemodynamic therapy in cardiac surgical patients. Anesth Analg 2000, 90:1052-1059.
13. Wakeling HG, MCFall MR, Jenkins CS, Woods WG, Miles WF, Barclay GR, Fleming SC: Intraoperative oesophageal Doppler guided fluid management shortens postoperative hospital stay after major bowel surgery. Br J Anaesth 2005, 95:634-642.

14. Gan TJ, Soppitt A, Maroof M, el-Moalem H, Robertson KM, Moretti E, Dwane P, Glass PS: Goal-directed intraoperative fluid administration reduces length of hospital stay after major surgery. Anesthesiology 2002, 97:820-826.

15. Mythen MG, Webb AR: Perioperative plasma volume expansion reduces the incidence of gut mucosal hypoperfusion during cardiac surgery. Arch Surg 1995, 130:423-429.

16. Noblett SE, Snowden CP, Shenton BK, Horgan AF: Randomized clinical trial assessing the effect of Doppler-optimized fluid management on outcome after elective colorectal resection. Br J Surg 2006, 93:1069-1107.

17. Sinclair S, James S, Singer M: Intraoperative intravascular volume optimisation and length of stay after repair of proximal femoral fracture: randomised controlled trial. BMJ 1997, 315:909-912.

18. Venn R, Steele A, Richardson P, Poloniecki J, Grounds M, Newman P: Randomized controlled trial to investigate influence of the fluid challenge on duration of hospital stay and perioperative morbidity in patients with hip fractures. Br J Anaesth 2002, 88:65-71.

19. Pearse R, Dawson D, Fawcett J, Rhodes A, Grounds RM, Bennett ED: Early goal-directed therapy after major surgery reduces complications and duration of hospital stay: a randomised, controlled trial [ISRCTN38797445]. Crit Care 2005, 9:R687-R693.

20. Lopes M, Lopes MR, Oliveira MA, Pereira VO, Lemos IP, Auler JO Jr, Michard F: Goal-directed fluid management based on pulse pressure variation monitoring during high-risk surgery: a pilot randomized controlled trial. Crit Care 2007, 11:R100.

21. Kern JW, Shoemaker WC: Meta-analysis of hemodynamic optimization in high-risk patients. Crit Care Med 2002, 30:1686-1689.

22. Brandstrup B, Tønnesen H, Beier-Holgersen R, Hjortsø E, Ørding H, LindorffLarsen K, Rasmussen MS, Lanng C, Wallin L, Iversen LH, Gramkow CS, Okholm M, Blemmer T, Svendsen PE, Rottensten HH, Tai B, Riis J, Jeppesen IS, Teilum D, Christensen AM, Graungaard B, Pott F, Danish Study Group on Perioperative Fluid Therapy: Effects of intravenous fluid restriction on postoperative complications: comparison of two perioperative fluid regimens: a randomized assessor-blinded multicenter trial. Ann Surg 2003, 238:641-648.

23. Nisanevich V, Felsenstein I, Almogy G, Weissman C, Einav S, Matot I: Effect of intraoperative fluid management on outcome after intraabdominal surgery. Anesthesiology 2005, 103:25-32.

24. Holte K, Foss NB, Andersen J, Valentiner L, Lund C, Bie P, Kehlet H: Liberal or restrictive fluid administration in fast-track colonic surgery: a randomized, double-blind study. Br J Anaesth 2007, 99:500-508.

25. Lobo DN, Bostock KA, Neal KR, Perkins AC, Rowlands BJ, Allison SP: Effect of salt and water balance on recovery of gastrointestinal function after elective colonic resection: a randomised controlled trial. Lancet 2002, 359:1812-1818.

26. Khoo CK, Vickery CJ, Forsyth N, Vinall NS, Eyre-Brook IA: A prospective randomized controlled trial of multimodal perioperative management protocol in patients undergoing elective colorectal resection for cancer. Ann Surg 2007, 245:867-872.

27. Rahbari NN, Zimmermann JB, Schmidt T, Koch M, Weigand MA, Weitz J: Metaanalysis of standard, restrictive and supplemental fluid administration in colorectal surgery. Br J Surg 2009, 96:331-341.

28. McArdle GT, McAuley DF, McKinley A, Blair P, Hoper M, Harkin DW: Preliminary results of a prospective randomized trial of restrictive versus standard fluid regime in elective open abdominal aortic aneurysm repair. Ann Surg 2009, 250:28-34.

29. González-Fajardo JA, Mengibar L, Brizuela JA, Castrodeza J, VaqueroPuerta C: Effect of postoperative restrictive fluid therapy in the recovery of patients with abdominal vascular surgery. Eur I Vasc Endovasc Surg 2009, 37:538-543.

30. Eagle KA, Brundage BH, Chaitman BR, Ewy GA, Fleisher LA, Hertzer NR, Leppo JA, Ryan T, Schlant RC, Spencer WH, Spittell JA Jr, Twiss RD, Ritchie JL, Cheitlin MD, Gardner TJ, Garson A Jr, Lewis RP, Gibbons RJ, O'Rourke RA, Ryan TJ: Guidelines for perioperative cardiovascular evaluation for noncardiac surgery. Report of the American College of Cardiology/American Heart Association Task Force on Practice 
Guidelines. Committee on Perioperative Cardiovascular Evaluation for Noncardiac Surgery. Circulation 1996, 93:1278-1317.

31. Prytherch DR, Whiteley MS, Higgins B, Weaver PC, Prout WG, Powell SJ: POSSUM and Portsmouth POSSUM for predicting mortality. $\mathrm{Br} J$ Surg 1998, 85:1217-1220.

32. American College of Chest Physicians/Society of Critical Care Medicine Consensus Conference: Definitions for sepsis and organ failure and guidelines for the use of innovative therapies in sepsis. Crit Care Med 1992, 20:864-874.

33. Lobo SM, Lobo FR, Polachini CA, Patini DS, Yamamoto AE, de Oliveira NE, Serrano P, Sanches HS, Spegiorin MA, Queiroz MM, Christiano AC Jr. Savieiro EF, Alvarez PA, Teixeira SP, Cunrath GS: Prospective, randomized trial comparing fluids and dobutamine optimization of oxygen delivery in high-risk surgical patients. Crit Care 2006, 10:R72.

34. Sark Y, Vincent JL, Reinhart K, Groeneveld J, Michalopoulos A, Sprung CL, Artigas A, Ranieri VM, Sepsis Occurrence in Acutely III Patients Investigators: High tidal volume and positive fluid balance are associated with worse outcome in acute lung injury. Chest 2005, 128:3098-3108.

35. Møller AM, Pedersen T, Svendsen PE, Engquist A: Perioperative risk factors in elective pneumonectomy: the impact of excess fluid balance. Eur $J$ Anaesthesiol 2002, 19:57-62.

36. Bennett-Guerrero E, Feierman DE, Barclay GR, Parides MK, Sheiner PA, Mythen MG, Levine DM, Parker TS, Carrol SF, White ML, Winfree WJ: Preoperative and intraoperative predictors of postoperative morbidity, poor graft function, and early rejection in 190 patients undergoing liver transplantation. Arch Surg 2001, 136:1177-1183.

37. Futier E, Constantin JM, Petit A, Chanques G, Kwiatkowski F, Flamein R, Slim K, Sapin V, Jaber S, Bazin JE: Conservative vs restrictive individualized goal-directed fluid replacement strategy in major abdominal surgery: a prospective randomized trial. Arch Surg 2010, 145:1193-200

38. Hiltebrand LB, Kimberger O, Arnberger M, Brandt S, Kurz A, Sigurdsson GH: Crystalloids versus colloids for goal-directed fluid therapy in major surgery. Crit Care 2009, 13:R40.

39. Lobo SM, Orrico SR, Queiroz MM, Contrim LM, Cury PM: Comparison of the effects of lactated Ringer solution with and without hydroxyethyl starch fluid resuscitation on gut edema during severe splanchnic ischemia. Braz J Med Biol Res 2008, 41:634-639.

40. Jhanii S, Thomas B, Ely A, Watson D, Hinds CJ, Pearse RM: Mortality and utilisation of critical care resources amongst high-risk surgical patients in a large NHS Trust. Anaesthesia 2002, 63:695-700.

41. Warrillow SJ, Weinberg L, Parker F, Calzavacca P, Licari E, Aly A, Bagshaw S, Christophi C, Bellomo R: Perioperative fluid prescription, complications and outcomes in major elective open gastrointestinal surgery. Anaesth Intensive Care 2010, 38:259-265.

42. Brandstrup B, Svensen C, Engquist A: Hemorrhage and operation cause a contraction of the extracellular space needing replacement: evidence and implications? A systematic review. Surgery 2006, 139:419-432.

doi:10.1186/cc10466

Cite this article as: Lobo et al:: Restrictive strategy of intraoperative fluid maintenance during optimization of oxygen delivery decreases major complications after high-risk surgery. Critical Care 2011 15:R226.

\section{Submit your next manuscript to BioMed Central and take full advantage of:}

- Convenient online submission

- Thorough peer review

- No space constraints or color figure charges

- Immediate publication on acceptance

- Inclusion in PubMed, CAS, Scopus and Google Scholar

- Research which is freely available for redistribution

Submit your manuscript at www.biomedcentral.com/submit
Biomed Central 